Archaeological Journal

\title{
Notes on the Heraldic Exhibition, Edinburgh, 1891
}

\section{J. Balfour Paul F.S.A. Scot.}

To cite this article: J. Balfour Paul F.S.A. Scot. (1891) Notes on the Heraldic Exhibition, Edinburgh, 1891, Archaeological Journal, 48:1, 416-425, DOI: 10.1080/00665983.1891.10852488

To link to this article: http://dx.doi.org/10.1080/00665983.1891.10852488

曲 Published online: 15 Jul 2014.

Submit your article to this journal $₫$

View related articles $\sqsubset$ 
NOTES ON THE HERALDIC EXHIBITION, EDINBURGH, 1891.1

By J. BALFOUR PAUL, F.S.A. Scot., Lyon King of Arms.

I wish in what I am going to say to point out briefly some of the most interesting exhibits in the collection of articles relating to heraldry which has been temporarily got together in view of the meeting of this Institute. I think such a collection will be found to be not altogether without its use. Archaeologists are of course divided into many classes, but few of them ran afford to dispense with some knowledge at least of heraldry. If you wish to study ancient buildings what a flood of light do those achievements, cut on their weather-beaten walls, throw on their history ; if you are a charter student what a personal interest do those quaint seals often give to the musty parchments ; if you are a grubber amongst old books-and what more engrossing pursuit-with what joy do you come across some ancient MS., its pages commemorative of the deeds of some illustrious race, and resplendent with illuminations fresh as they came from the hand of the patient scribe who gave such loving labour to his task long centuries ago. Or are you an artist interested in studying the effective combination of colour? You will find it a singular fact that whether you look for harmony or contrast in the colours of heraldic emblazonment you will never find a coat that jars on the artistic taste. The rule which prohibits colour being on colour or metal on metal seems a safeguard against all offending combinations. And what more beautiful in the way of heraldic art than those "storied windows richly dight" which we find in our old churches; from generation to generation they have blushed and glowed in the warm sunlight till their colours are mellowed to a softened radiance, and they form one of the most beautiful records of the past. And though we have, I am afraid, lost the art of making that quality of glass which our ancestors possessed, we can still employ heraldic decoration to as great effect in other ways. The art of embroidery is still as popular with our ladies as it ever was, and you can see for yourselves from several specimens in the exhibition what beautiful work may be done with the needle in the ornamentation of textile fabrics.

It is, however, through the art of the illuminator that heraldry appeals niost strongly to the popular taste. Persons who know nothing of heraldry as a science, and who are not interested in tracing the descent of a family and exploring its various alliances, can stili admire a finely executed blazon, appealing, as it does, to their artistic sense. Look, for instance, at the Grant of Arms to the Tallow Chandlers Company of the City of London. It is one of the oldest, if

1 Read in the Antiquarian Section at the meeting of the Institute, at Edinburgh: August 14th, 1891 . 
not the oldest, grant in existence. It is given by John Smart, Garter King of Arms, on 24th September, 1454, thirty years before the present College of Arms was incorporated. Old as it is, or rather, indeed, beause it is so old, it is one of the most beautiful specimens of the scriveners art that we possess. The floriation of the mantling and other accessories of the coat of arms are executed with a delicacy of feeling and artistic restraint which we look for in vain in later examples. However useful the art of printing may have proved there is no doubt that from its introduction the decadence of the art of illuminating and writing MS. may be dated. The grants of arms of the next century are tawdry and stiff in comparison with their predecessors, and indeed it may be said that the art of blazoning has never again reached such high artistic excellence as it did in its early dajs. As we shall bave occasion to observe, vigour of a sort was not wanting in some of the heraldic artists of the sixteenth century, but it was vigour unaccompanied by that knowledge of form and instinctive grace which characterized the earlier exponents of the art. In the reign of Charles II. we find no lack of gorgeousness of colouring and elaboration in detail, but the general effect is heary though rich. A fine example of the blazonry of this period may be seen in the interesting Deed of Recognition by Charles II., of the Royal descent of the Cantelmo family. This family first settled in France, whence they accompanied Charles of Anjou to Naples. They claimed to be descended from Duncan, King of Scotland, but they rather illogically styled themselves at one period of their history Cantelmo-Stuarts. They bear as arms a lion rampant surmounted by a label of three points. Personally I have not yet had an opportunity of reading King Charles's recognition, so that I cannot say on what evidence the document proceeded. Apart from historic and family interest, however, it is a good specimen, as I previously remarked, of the style of the period. Another deed, belonging to the same reign, and displaying similar richness of ornamentation, is (No. 242) a commission by the King to Sir James Leslie, Knight of the Golden Spur, to be Ambassador to "the High and Glorious Monarch, the Mighty and Right Noble Prince Abunazar Mutey Ismael Aben Mutania Sherif Mutey Ali, the present Emperor of the Kingdom of Fez Morocco."

But to come back to the earlier illuminations which after all are in every way the more interesting. As regards grants of arms, England easily bears off the palm, both in respect of beauty of design and artistic treatment. In Scotland we have nothing to compare to them. What are probably the two earliest Scottish grants in existence are both exhibited, one to Sir James Balfour of Pittendreich, and the other to Lord Maxwell of Herries. They are both rude and untutored in the design, but are not without a certain graphic strength. The same remark applies, though in a less degree, to the early Scottish armorials, a fine collection of which has been got together. It begins with the important and authoritative MS. of Sir David Lindsay of the Mount. This, of course, is one of the best known heraldic MS. in existence, as no less than two fac-simile editions of it have been published. While it does not pretend to any very high artistic excellence, it is distinguished by solid and sufficient work ; but it is, of course, as a register of arms, executed under the direction of the highest heraldic authority of the time, and sanctioned in the next century by 
the Privy Council of Scotland that this armorial commands our attention. There is a curious reference to it in a letter from Thomas Randolph, the English Envoy to the Scottish Court, to Sir William Cecil, dated 5 October, 1561. when, after commending to his correspondent, the bearer of the epistle, David Lindsay, of Rathillet, then Rothesay Ferald, youngest brother of Sir David (afterwards himself Lyon in 1568) he continues "To lette hym be the better knowne unto your honour he is brother unto the notable David Lindsaye, Kynge of Armes. He is hable to procure me the syghte of a book with one word of your honours mouth wherein are all the armes of all the noblemen and barons bothe newe and olde."

The armorials of the last half of the sixteenth century, of which several are exhibited, display a curious similarity of form and treatment. They generally begin by giving the mythical coats of the three Kings of Cologne and personages mentioned both in sacred and profane history. Then come full length representations of the Kings and Queens of Scotland, each clad in a surcoat with their appropriate coat of arms. That of Baliol is peculiar, being always depicted with shattered crown, broken sword and sceptre, and rent surcoat, sometimes also lying on the ground, as if to typify the disgrace he was considered to have brought on the country. The most interesting as well as the most artistic armorial connected with Scotland, however, is that from the Archerfield Library (671), and which is, I believe, for the first time brought under public notice. Its history deserves a word of mention. The first owner of the book of whom we have any record was George Lord Seton, the devoted adherent of Queen Mary, who met her on the shores of Loch Leven, and who was afterwards exiled for adherence to her cause. On his death in 1585 it became the property of his son Robert, afterwards Earl of Winton, and about 1630 it was acquired by James Espline Marchmont Herald, subsequently passing into the possession of William Nisbet of Dirleton, to whose representative it still belongs. This armorial marks a distinct advance in respect of artistic treatment on anything which had been previously seen. The figures of the Scottish monarchs "are full of variety and individuality, and in all of them there is a manifest aim to adhere with antiquarian accuracy to the costume of the various periods." The faces are evidently intended to be portraits, and agree with the traditional representations of the monarchs. James IV. is depicted with an iron chain round his waist, which, according to tradition, he wore constantly next his skin in expiation of his rebellion against his father, and by means of which his body is said to have been identified after the battle of Flodden. The effigies of James VI. and his Queen are particularly rich and elaborate, a purple canopy being introduced, blazoned with the arms of Scotland impaling Denmark. The page showing the "Habit of a Herald 1500 " is curious, the head of the figure being covered with a winged cap, and the right hand holding the serpent-twined caduceus of Mercury. While no doubt the regulation tabard is displayed, I rather think that the entire representation savours more of the allegorical than the historic. The details of the blazoning throughout the remainder of the volume are full of interest to the heraldic stuclent, but I have not time to enter on them here. I can only allude very briefly to two more of the Scottish armorials. One 
is that from the Sunderland Hall Library (674), dating from the early part of the reign of James VI. "The execution of the arms in this volume is very distinctive. The shields are strongly outlined in black. The handling is firm. and determinative, without being at all delicate or sensitive. The animals are drawn with vigour and spirit but when the human figure is introduced it is expressed in a singularly rude and inadequate fashion." There are various eccentricities of orthography which seem to point to the hand of a foreign painter having been employed. One of the odd features about the volume is the curious variations from the usually accepted arms which occur. In the case of Lord Somerville for instance, Nisbet gives the crest as a wheel or, and upon it a dragon vert spouting fire; here, however, it is given as a frog, while the supporters, usually given as two hounds proper collared gules, are represented under the eccentric guise of two frogs, or, to give them their vernacular Scottish names, "puddocks." Several other examples of similar variations might be mentioned. The other Scottish armorial to which I wish to direct your attention is (No. 678) from Dunvegan Castle. It was once the property of Brodie of Brodie (Lyon King of Arms 1727-1754), whose daughter and heiress married into the family of Macleod of Macleod, in whose possession it still remains. It was at one time supposed to have belonged to, if it was not executed by, Guillaume du Bartas, Ambassador to James VI., a well-known poet, who fought at Ivney, celebrated the battle in his song, and died of wounds received on the field. The ground for this belief was an autograph inscription at the end of the volume, "I 'ay laisse' mes armories a Mons. Scha, en tesmoinage d'amitie, Du Bartas," which has been held as presenting or bequeathing the book to William Schaw, Master of the King's Worls, and Chamberlain to the Queen of James VI. A closer investigation of the book, however, shows that this cannot be the case, and the conclusion has been come to, which is probably correct, that the volume is simply a Liber. Amicorum of a kind quite common in that age, and of which several other specimens nay be seen in the exhibition. The inscription referred to has been evidently intended to have been put below a drawing of the arms of Du Bartas, but this has never been executed, the page being blanls save for the inscription at its foot and the words "ex arte et marte" (doubtless the Du Bartas motto) at the top. The work itself is a beautiful armorial, the various coats being executed in a brilliant and artistic manner.

I would fain linger over some of the other armorials, both Scottish and English, but time warns me that I must pass to other subjects after a glance at the Foreign Collections of arms. But before doing so I would asl you not to omit seeing the curious armorial (No. 685) belonging to the Lyon Office. It is not an ancient one, only dating from 1707 ; it is a MS on vellum containing the arms of the nobility of Great Britain. The peculiarity which makes it probably a unique volume consists in all the details of the arms, the charges in the shield, the supporters and the minutest details on then-, the crest, \&c., being cut out separately and pasted on to the vellum; for instance in the case of Lord Reay's supporters, which are two soldiers, their belts, cartouche boxes, firelocks, ejpaulettes, and, if I remember rightly, the very buttons are separate pieces of work, and neatly joined together. 
Foretcin Armortals.

Most of the foreign exhibits will be found in the second room of the exhibiti:n. In the case of the armorials they are represented by fac-simile reproductions. Though I have not seen any of the original MS I cannot believe that their hues are not considerably more subdued and softened than those of the reproductions here exhibited, which exhibit a very clecided use of the analine colours. One of the earliest and most interesting armorials in existence is the Zurich Roll (751). It is believed on good grounds to be a MS of the 14th century, probably executed at Zurich between 1336 and 1347. Simple, vigorous, and quaint in the style of treatment adopted, and elfective though thoroughly artistic in its colouring it is an admirable example of a mediæval register of arms. Not less important and much more elaborate, though a century later in date, is the splendid Armorial de Gelre, the original of which is now in the Royal Library at Brussels. It has been reproduced in extenso by M. Victor Bouton, whose edition may be seen in Case XIV. (1018).

Heyneu the author, who was Gelre Herald of the time, had travelled widely and observed narrowly; the result was that he included in his armorial a great variety of arms belonging to the sovereigns, nobles, and Princes of Europe. The 5 are exesuted in a most masterly and graphic manner ; the animals are instinct with life, and the colouring is brilliant and harmonious. From the large number of arms which are represented they are necessarily on a somewhat small scale, but their decorative effect may be easily seen by the enlargements of a few of them which have been made, and which will be found hanging separately on the wall (753). The series of equestrian figures (779-793) representing the Knights of the Golden Fleece, are worthy of notice. They are taken from an armorial in the Arsenal Library in Paris, which has been recently edited by $\mathrm{M}$. Loredan Larchey. Its date is previous to 1467 . It contains a series of seventy four mounted figures, beginning with Philip the Good, founder of the Order of the Golden Fleece, and includes most of the Monarchs, Princes, and Elector Bishops of Europe, each brandishing a short sword, displaying his crest on his helmet, and bearing his full heraldic achievement emblazoned on his surcoat and horse trappings. As a very competent authority remarks, "Later in date than the Armorial de Gelre, this MS shows less of delicacy and refined grac6; the Flemish influence is more pronouncedly present in its art; but these equestrian figures are full of a quaint 'Gothic gusto' of the very essence of mediævalism, and they enable us to realise with a quite curious vividness the fantastic yet splendid aspect of the knight of the period when fully equipped for the tilting lists, and enable us to study every minutest detail of his armour and weapons." From this point of view a still more extraordinary set of figures are those delineated in the plates (1088) from the tournament book of William, Grand Duke of Bavaria. They show the extravagance and absurd elaboration of the equipment of German IKnights and their steeds in the first half of the 16th century, contrasting with the simple and workmanlike armour of our own country; the whole in fact may be designatec chivalry gone mad. The only other foreign armorial to which I would allude is that by Conrad von Granenbery, completed at Constance 1483, and recently reproduced in admirable fac-simile. It is one of the most important armorials extant, and is, says 
the authority I have quoted above, "thoroughly representative of the period when heraldic delineation and illumination attained its most exuberant richness; in which while the restraint of earlier times was rapidly passing away, it was still informed by a certain dignity and $a$ noble conventionalism." Many most interesting technical points in this armorial appeal to the heraldic student, but I cannot even mention them, and must now pass, after recommending to your attention the three very beautiful MSS lent by Her Majesty the Queen (case xx).

\section{HrstortCal Exhrbits.}

Not the least interesting part of the collection we are naming consists of those articles of very diverse kinds which have some definite historical association. Among these may be mentioned the great Cavers Banner, which will be found on the floor of the large case in the first ronm. This curious relic consists of a flag of thin sage green silk twelve feet long by three wide, bearing certain heraldic devices - the details of which you will find on the catalogue-painted on it. It is said to have been the banner of James, Second Earl of Douglas and Mar, and was carried by his son, Archibald Douglas, of Cavers, at the Battle of Otterburn, 1368. If this is so-and I see no reason to doubt the truth of the tradition-it is one of the oldest flings in existence, and it is in a wonderful state of preservation. Associated with this and belonging to the sarue time are the "Percy Gauntlets" (71), said to have been attached to Hotspur's lance as a "Gage d'Armour," which Douglas took from him when he overthrew him in single combat before the walls of Newcastle in the year before-mentioned. They are delicate and beautifully embroidered gloves, though mure fitted for the boudoir than the camp. Near these you will see another ancient family banrer, in the shape of the Bellenden banner (151) anciently carried by the Scotts of Buccleuch, and bearing their arras surmounted by an earl's coronet. Another celebrated old Scottish flag is represented hy il photograph, but the original may be seen in the Advocates' Library in this city. It is the standard of the Earl Marshal of Scotland, carried at the Battle of Fludden by Black John Skirving of Plawland Hill, the Standard-bearer. Having been taken prisoner, Skirving concealed the banner about his person, and it remained in the possession of the family till the beginning of this century, when it was presented to the Faculty of Advocates. A fine piece of emblazonment which has an interest for both English and Scots, will be found in case viii. (693) in the actual copy of the Statutes of the Order of the Garter illuminated on vellum, sent by Henry VIII. to James V. of Scotland on his installation as a Knight of the Order, 1535. What is additionally interesting is that there has been discovered the account of expenses for the production of this document, so that we are able to tell exactly what the whole thing cost. Near this you will see what is perhaps the most important exhibit of its kind in the exhibition. This is a Book of Hours of the 13th century, a most exqusite MS, but the chief interest of which consists in having recorcled in its calendar against the 26 th of April the death of Sir John Stewart, the Blick Knight of Lorne, which took place in 1421. The death of his wife Isabella, the heiress of Lorne, is also noted as having occurred on 2lst December, 1439. But the interest of the MS does not end here. 
Bound up with it, but in the opinion of experts totally unconnected with the volume originally, and certainly nearly a century older, is a series of 23 full page illuminations representing scriptural subjects, and bearing traces of Saxon influence. One of these displays the Roman soldiers watching the tomb of Our Lord; they are four in number, and "clad in complete steel," and their shields aro emblazoned with distinct heraldic charges. If we are right in assuming these illuminations to have been produced previous to the end of the 12th century, we have in them some of the very earliest representaiions of coats of arms, and they show that heraldry had then attained to a more advanced stage than is generally consider'ed to be the case.

While there are many other noteworthy historical clocuments to be seen in the exhibition, especially several interesting and beautiful documents of Charles V., Philip I., and Philip II. of Spain, I can here only mention two more. One is the protest (3s8) of the Buhemian nobles against the burning of John Huss and Jerome of Prague, addressed to the Council of Constance in 1415, und having ninety-nine seals attached. The seals, unfortunately, are worn and rubbed, but the deed is one which will appeal in a special way to the feelings of many. It is the property of the University of Edinburgh, having been bequeathed to it in 1657 by Dr. William Guild, Principal of Kings College, Aberdeen. Another most interesting relic intimately associated with this country is the lovely little gold signet which you will see in case vii. (1167). It was found durinis some excavations at Kinross in 1829 , and from the fact that 2 horseshoe was found near it it is surmised that its original possessor may have been thrown at the place, and so lost the signet. At first the seal was supposed to be the personal signet of James $I V$, bearing as it did the Scottish Lion impaling the arms of England for his Queen, Margaret Tudor, daughter of Henry VII. A narrower investigation, however, disclosed the presence of the bordure compony of the Beauforts proclaiming the arms to be those of Joan Benufort, daughter of John, Earl of Somerset, the English beauty who had captivated the heart of our James I. during his captivity in the south. It is a most perfect specimen of the seal engraving of the period, executed with exquisite refinement, and fresh and bright as on the day it left the hands of the maker. Behind it are two thin semi-circular plates of gold attached to the centre of the back of the seal with a hinge, so as to fall upon it flat, and enable it to be conveniently carried in the pocket. $A$ more interesting almost pathetic relic of a.lady who had a bright future before her as the wife of an able and gallant king, but whose after life was spent in pursuing the assassins of her ill-fated husband, it would be difficult to find.

\section{Printed Boors.}

But we must hasten on, and I can only indicate to you very briefly before closing a few more of the special features of the collection. Those of you who are collectors of books will find a fair selection of the heraldic works which have been published in this country, and had we had a little more time and space at our disposal I do not think it would have been impossible to have got together a complete collection. I need not do more than mention the names of the Boke of St. Albans and Gerard Ieigh's Accedence of Armorie, both of which quaint works are well-known to every student of heraldic antiquities. The copy of 
Ferne's Blazon of Gentrie-a work not very readable at best--which will be found in case No. vii. $(111 A)$, has an especial interest of its own attaching to it ; it is from the Abbotsford Library, and was the property of Sir Walter Scott; a previous owner was Thomas Irysdale, Islay Herald, who had bought the book in 1619 , and who seems, Sir Walter says, to have read it with patience and profit till he came to a passage which quotes Scotland and England as "examples of feudatory and sovereign powers." This assertion set on fire the Scottish blood of Islay Herald, who, forgetting the book had been printed nearly forty years before, and that the author was probably deal, writes on the margin in great writh and in a half-text hand " $\mathrm{He}$ is a traitor and a lyar in his throat, and $I$ offer him the combat that says Scotland's Kings were ever feudatory to England." The Union of Honour (119) is worthy of a glance, were it only for the fact that it is the work of one of thuse genealonists who, like poets, are born, not made. Its auther was James Yorke, who is quaintly described by Fuller in his "Worthies of Lincolnshire" as "a blacksmith of Lincolne, and an excellent workman in his prnfession, inasmuch that if Pegasus himself would wear shoes this man alone is fit to make them, contriving them so thin and light as that they woulı be no burden to him. But he is a servant as well of Apollo as of Vulcan, turning his stidly into a study, having lately set forth a book of heraldry callel 'The Union of Honour, \&c.,' and although there be some mistakes (no hand so steady as always to hit the nail on the head), yet it is of singular use and industriously performed, being set forth since 1640." The collectors will not fail to note Randle Holmes' Academy of Armory as probably the rarest bunk on the subject, not more than fifty copies being known to be in existence. Its contents embrace a vast variety of subjects from Heraldry to the sibyls, grammar, and billiards. A passing mention of a fine hand-coloured edition of the great work of Guillim must close our hasty glance at the printed books, though I must ask you not to forget to look at the works of one whom I consiller, if you will pardon what is perhaps national partiality, the best of all the older heraldic writers, I mean Alexander Nisbet.

\section{SHALs.}

The subject of seals is one which appertains so much to the domain of the speciulist that it would be useless to enter on it here in any detail. I can but point ont to you the fine series of casts selected from the collec tion of the Society of Antiquaries, Lnndon, by their Assistant Secretary, Mr. St. John Hope, as illustrating the rise, progress, and decline of seal engraving in England. I must not, too, omit to mention the series of Scottish great seals for which we are also indebted to the same Society. The fac-similes of sicottish seals (all of which you will find reproduced in Henry Laing's admirable work) show that Scotland was not behind her neighbours in the mildle ages in respect of the art of seal engraving, and is perhaps the clearest and most complete proof that is extant of the arlistic vitality of the Scottish nation from the thirteenth to the sixteenth century. From the commemoration of one man in his personal signet to that of many in a family tree is a natural enough transition, and I would ask you to turn from the seals and look at two noble pedigrees which hang on the walls. The large one (No. 1) is the "Genealogie of the most ancient and noble House of Douglas," and contains much that 
is of interest both to the herald and genealogist. The artist, too, cannot fail to be arrested by the tree of the Campbells of Genurquhy, executed as it was by Jameson, the early Scottish portrait painter, and embellished by portraits, or at least representations of various members of the family, by his hand. The photograph of the Seton Pedigree (5) displays an extraordinary and delicately executed family tree with small portraits of some of the members, together with apes and peacosks inter.spersed in the foliage of the branches.

A few desultory observations on the miscellaneous objects in the axhibition must close this paper. Let me direct ynur attention to the splendid series of portraits of Kings of Arms, Heralds, Pursuivants, and writers on Heraldry lent by Mrr. Arthur Vicars, of Dublin. Such a collection, amounting to about 100 items, is, I should think, quite unique, and must have taken much time and labour to bring together. The assemblage of Heralric Playing Cards exhibited on the wall opposite to that where the heralds are, is from the collection of $\mathrm{Mr}$. Clulow, London, who, I believe, has the most famous collection of playing cirds in the world. These heraldic cards illustrate the popularity of the science in days gone by, especially on the Continent, ther: being specimens of French, German, Russian, and Italian packs, as well as Iing'ish. Sentland, too, can boast of a similar set of cards, which are disp':uyed along one of the shelves in the large glass case. Several sets of these are known to be in existence. One is at Abbotsford, another is or was (because recent inquiries have failent to find it) at Drummond Castle, and the pack which the Committee have been fortunate enough to secure belongs to Miss Crichton, of Musselburgh.

You must not omit to look at the series of sketches illustrating the heraldic features incorporated into the architecture of some of the principal mansions in Scotland. They are the work of Messrs. Macgibbon and Ross, architects, executed for their book on the Castellated and Domestic Architecture of Srotland, a work of which three volumes have been published, and which is now on the eve of completion. I do not think I exagrerate when I say that it is quite the most important book on the subject that has ever been published in Scotland, and both for artistic excellence and accuracy of detail will remain the standard work of its kind.

To those whose tastes incline to the splendour and solemnity of state ceremonial, the collection of the decorations of the various orlers of Knighthood, kindly lent us by the Lord Chamberlain, cannot fail to be attractive. It must be confesserl that the art of designing collars, badges, and the like has not progressed in recent times. Both the Garter and Thistle collars are much more artistic thin those of the more modern orders, but it is a question whether the much simpler and less pretentious collar of SS. (about the origin of which so much has been written-see 'Notes and Queries' passim) is not as handsome and pleasant to look on as any of them. The row of tabards in the large glass case makes a brilliant display, though in the more modern specimens the colours are somewhat too vivid. The beautiful and elaborate work on them, nowever, should interest our lady visitors, You will notice one (141) once the property of Bath King of Arms, which was in use before the French fleurs de lys were removed from the Royal ensigns armorial. The Crown of a King of Arms which is shown is quite monumental in its poverty of design and clumsiness of execution, 
The stained glass in the exhilition, though small in quantity, is good in quality. There are two glorious old bits (probably German), (1097-9s) whose brilliant hues have been mellowed by the touch of ages, till now they are perfect specimens of their kind. A fine panel, too, is that bearing the arms of James VI, and his Queen, showing Scotland impaling Denmark, of date 1600 , and $\mathrm{Mr}$. Albert Hartshorne has lent us an interesting piece, representing a traditional incident in the life of Sir Alexander Stewart with a border round it, dated, 1574. The four paintings over the doorway leading to the second roon of the exhibition, represent a fine armorial window in the Magdalene Chapel in the Cowgate of this city. It is, perhaps the oldest specimen in Scotland of painted glass in situ, and though, of course, the glow of the original cannot be reproduced with the brush, the skillful way in which the general effect has been reproduced cannot but be admired.

And now I can only recommend you in a word to look at the beautiful exhibits lent by the authorities at South Kensington, both in metal and needlewcrk-at the artistic display of china which has been got both from private individuals and the Edinburgh Industrial Museum, and at the fine collection of rubbings from the heraldic brasses which have been chosen from a large number which are at the last named institution. Lastly, collectors of book-plates will find a considerable number to study which the Committee have culled from inmonse collections which have been put at their disposal.

I have in the above imperfect notes encleavoured to point out to you some of the most conspicuous artivles in the exhibition. It is only a very hurried survey that we have been able to take, but if the result is to enable you to go to the exhibition with some clefinite idea of what you are to see. and to see it from a point of view from which, perhaps, you had not considered it before, the paper will not have been written in vain. Though largely archneological in character, the result will, I hope, prove that heraldry, looked at both from its scientific and artistic sides, is still living and flourishing, displaying, especially within the last few ycars, renewed energy and vigorous growth. 